\title{
KRAS and BRAF mutations in serum exosomes from patients with colorectal cancer in a Chinese population
}

\author{
YI-XIN HAO $^{1 *}$, YONG-MEI LI ${ }^{2 *}$, MING YE $^{1}$, YAN-YAN GUO ${ }^{1}$, QIU-WEN LI ${ }^{1}$, XIU-MEI PENG ${ }^{1}$, QI WANG ${ }^{1}$, \\ SHU-FANG ZHANG ${ }^{1}$, HUI-XIA ZHAO ${ }^{1}$, HE ZHANG $^{1}$, GUANG-HUI LI ${ }^{1}$, JIAN-HUA ZHU ${ }^{1}$ and WEN-HUA XIAO ${ }^{1}$ \\ ${ }^{1}$ Department of Oncology, The First Affiliated Hospital of The People's Liberation Army General Hospital, Beijing 100039; \\ ${ }^{2}$ Department of Oncology, Changhai Hospital, Second Military Medical University, Shanghai 200433, P.R. China
}

Received August 20, 2015; Accepted January 26, 2017

DOI: $10.3892 / 01.2017 .5889$

\begin{abstract}
The efficacy of epidermal growth factor receptortargeted therapy is significantly associated with Kirsten rat sarcoma viral oncogene homolog (KRAS) and B-raf serine/threonine kinase proto-oncogene (BRAF) mutation in patients with colorectal cancer (CRC), for which the standard gene testing is currently performed using tumor tissue DNA. The aim of the present study was to compare the presence of KRAS and BRAF mutations in the serum exosome and primary tumor tissue from patients with CRC. Genomic DNA were extracted from the tumor tissues of 35 patients with histologically-confirmed CRC and exosomal mRNA were obtained from peripheral blood, which were collected from the corresponding patients prior to surgery. Three mutations in the KRAS gene (codons 12, 13 and 61) and a mutation in the BRAF gene (codon 600) were detected using a polymerase chain reaction-based sequencing method and their presence were compared between tumor tissues and the matched serum exosomes. The KRAS mutation rates in tumor tissues and the matched serum exosomes were 57.6 and $42.4 \%$, respectively, which was not significantly different $(\mathrm{P}=0.063)$. The detection rate of the BRAF mutation was 24.2 and $18.2 \%$ in tumor tissues and the matched serum exosomes, respectively, and there was no significant difference $(\mathrm{P}=0.500)$. The patients with CRC that had a KRAS mutation of codon 12 in exon 2 in their tumor tissues and serum exosomes were significantly older compared with those without this mutation (tumor tissue, $\mathrm{P}=0.002$; serum exosome, $\mathrm{P}=0.022$ ). The sensitivity of KRAS
\end{abstract}

Correspondence to: Dr Yi-Xin Hao or Dr Wen-Hua Xiao, Department of Oncology, The First Affiliated Hospital of The People's Liberation Army General Hospital, 51 Fucheng Road, Haidian, Beijing 100039, P.R. China

E-mail: 15901537871@163.com

E-mail:w_hxiao@hotmail.com

*Contributed equally

Key words: Kirsten rat sarcoma viral oncogene homolog, BRAF serine/threonine kinase proto-oncogene, mutation, exosome, colorectal cancer and BRAF mutation detection using exosomal mRNA was 73.7 and $75 \%$, respectively. The specificity of the detected mutations exhibited an efficiency of $100 \%$, and the total consistency rate was 94.9 and $93.9 \%$ for KRAS and BRAF mutations, respectively. These results suggested that serum exosomal mRNA may be used as a novel source for the rapid and non-invasive genotyping of patients with CRC.

\section{Introduction}

Colorectal cancer (CRC) is one of the four most prevalent solid tumors that cause cancer-associated mortality globally. Early detection of CRC improves the 5-year survival rate from $12-13 \%$ in stage IV metastatic disease to $90 \%$ in stage I-II early-stage disease (1). Fecal occult blood test is typically used for CRC screening. Carcinoembryonic antigen (CEA) and carbohydrate antigen 19-9 (CA19-9) have been used for diagnosis and for disease monitoring following treatment. Although CEA and CA19-9 have exhibited a certain level of sensitivity, their sensitivity remains low. The pathological testing of tumor tissue is the optimal method for histological diagnosis, and the detection of mutations in rat sarcoma viral oncogene homolog [RAS; Kirsten RAS (KRAS) and neuroblastoma RAS (NRAS)] gene and B-raf serine/threonine kinase proto-oncogene (BRAF) gene in tumor tissue are used as predictive biomarkers aiding in the selection of targeted drug treatments (2). Colonoscopy of the primary tumor and needle biopsy of metastatic tumors are the techniques used for histological and genomic diagnosis; however, these methods are invasive, uncomfortable and costly (3-5). Thus, novel non-invasive methods for diagnosis and the detection of mutations are required.

Exosomes are small stable vesicles of $30-100 \mathrm{~nm}$ in diameter in the circulating blood, in which microRNA (miRNA/miR), mRNA and DNA fragments are coated in numerous proteins and bioactive lipids (6-9). Previous studies have identified that exosomes may be directly released from cells through the outward budding of the plasma membrane in a calcium-dependent manner, and be shuttled from donor cells to recipient cells (10-14). The level of exosomes released from cancer cells has been demonstrated to be increased compared with normal cells, and exosomal RNAs and proteins may implicate the origin of the donor cells $(15,16)$. Therefore, 
exosomes may serve as a highly sensitive and specific diagnostic tool for the repetitive and non-invasive monitoring of patients with cancer, aiding clinicians in the diagnosis, classification and treatment of cancer (17).

To validate the potential of the serum exosome as a novel biomarker for the monitoring of cancer, the current study investigated whether established cancer-associated mutations could be amplified from mRNA in the serum exosome of patients with cancer. In the present study, KRAS and BRAF gene mutations were detected in patients with CRC, and the consistency of the detection of these mutations between primary tumor tissues and the matched serum exosomes were compared. The results of the current study indicated that serum exosomal mRNA had the potential to be used for gene mutation detection in patients with CRC.

\section{Materials and methods}

Clinical samples. The current study consisted of 35 patients (age, 40-75 years; mean \pm standard deviation, 60.0 \pm 9.5 years) from The First Affiliated Hospital of The People's Liberation Army General Hospital (Beijing, China). Patients underwent tumor resection surgery between July 2013 and December 2013 with histologically confirmed colorectal adenocarcinoma prior to the surgery. Colorectal primary tumor tissue samples were obtained from the surgical specimens and the matched blood samples were obtained from the patients prior to the surgery. Detailed information of the patients were presented in Table I. The classification of tumor differentiation and stage were assessed according to the 2000 World Health Organization (WHO) classification system for tumors of digestive system and the American Joint Committee on Cancer (AJCC) staging system, respectively (18). The present study obtained ethical approval from the Ethics Committees of The First Affiliated Hospital of The People's Liberation Army General Hospital (no. 2013067) and informed written consents were obtained for all patients.

Exosomes were obtained from blood serum. Exosomes were prepared using the differential ultra-centrifugation method, as previously described (19). Blood serum (5 ml) was centrifuged at $500 \times \mathrm{g}$ for $10 \mathrm{~min}$, at 2,000 $\mathrm{x} g$ for $20 \mathrm{~min}$ and at $10,000 \mathrm{xg}$ for $10 \mathrm{~min}$, all at $4^{\circ} \mathrm{C}$. The supernatant was filtered through $0.22 \mu \mathrm{m}$ disposable filter units, and transferred to an Amicon ${ }^{\circledR}$ Stirred Ultrafiltration Cell (Model 8050) with a 100,000 KDa molecular weight cutoff ultrafiltration membrane (all EMD Millipore, Billerica, MA, USA) at a nitrogen gas pressure of $<75$ psi $\left(5.3 \mathrm{~kg} / \mathrm{cm}^{2}\right)$. The samples were stirred and the rate of stirring was adjusted so that the vortex created was $1 / 3$ the depth of the liquid volume. Following the supernatant ultrafiltration, $10 \mathrm{ml}$ PBS was added and ultra-filtrated three times. Following washing twice, $0.1 \mathrm{ml}$ PBS was added to suspend the exosomes. Subsequently, exosomes were isolated using ultra-centrifugation at $120,000 \mathrm{x}$ g for $1 \mathrm{~h}$ at $4^{\circ} \mathrm{C}$ and stored at $-80^{\circ} \mathrm{C}$. The purified exosomes from the microcapsule membrane structure $(30-80 \mathrm{~nm})$ were observed using a Hitachi H-7500 transmission electron microscope (Hitachi, Ltd., Tokyo, Japan; Fig. 1A). For immunoelectron microscopy, exosomes were incubated with a rabbit anti-human cluster of differentiation (CD)63 monoclonal antibody (dilution, 1:1,000; \#EXOAB-CD63A-1; System Biosciences Inc., Palo Alto,
CA, USA) for $1 \mathrm{~h}$, followed by $20 \mu \mathrm{l}$ Staphylococcal protein A Immunogold (dilution, 1:15; Meridian Life Science, Inc., Memphis, TN, USA) for $30 \mathrm{~min}$ at room temperature. Samples incubated with PBS were used as the blank control. The positively labeled exosomes were confirmed as vesicles containing black colloidal gold particles using a transmission electron microscope (Fig. 1B).

cDNA synthesized from exosomal mRNA. Total RNA were extracted from serum exosomes using the RNeasy Mini Spin kit (Qiagen $\mathrm{GmbH}$, Hilden, Germany) according to the manufacturer's protocol. A total of $1 \mu \mathrm{l}$ Oligo dT (5'-d(TTTTTT TTTTTTTTTTTT)-3') and $1 \mu 1$ random sequence (Takara Bio, Inc. Otsu, Japan) were added into the $10 \mu \mathrm{l}$ of RNA elution fluids, incubated at $70^{\circ} \mathrm{C}$ for $10 \mathrm{~min}$ and then on ice for $2 \mathrm{~min}$. For cDNA synthesis, reagents were added to the $12 \mu \mathrm{l}$ RNA mixture described above, resulting in final concentrations (in $20 \mu \mathrm{l}$ ) of $200 \mathrm{U}$ RNase M-MLV (RNase H-), $40 \mathrm{U}$ ribonuclease inhibitor, $10 \mathrm{mM}$ of each dNTP, $4 \mu 1$ XX M-MLV buffer (all from Takara Bio, Inc.) and RNase-free distilled $\mathrm{H}_{2} \mathrm{O}$. This reaction was incubated at $42^{\circ} \mathrm{C}$ for $1 \mathrm{~h}, 70^{\circ} \mathrm{C}$ for $15 \mathrm{~min}$ and then placed on ice. The cDNA products were stored at $-20^{\circ} \mathrm{C}$.

Polymerase chain reaction (PCR) of KRAS and BRAF. Genomic DNA were extracted from $100 \mathrm{mg}$ of tumor tissue using a standard protein kinase K procedure (20) and observed through separation on a $0.5 \%$ agarose gel and visualized by ethidium bromide (DL2000 DNA Marker, Takara Bio, Inc.). A total of $2 \mu \mathrm{l}$ DNA isolated from tumor tissue or $2 \mu \mathrm{l}$ cDNA from serum exosomes were added to result in the following final concentrations in a $20 \mu \mathrm{l}$ reaction: 5 units Ex Taq (Takara Bio, Inc.); $0.2 \mu \mathrm{M}$ of forward primer; $0.2 \mu \mathrm{M}$ of reverse primer. The primers used in the PCR are presented in Table II. These reactions were incubated at $95^{\circ} \mathrm{C}$ for $40 \mathrm{sec}$, followed by 40 cycles of $95^{\circ} \mathrm{C}$ for $10 \mathrm{sec}, 60^{\circ} \mathrm{C}$ for $20 \mathrm{sec}$ and $72^{\circ} \mathrm{C}$ for $20 \mathrm{sec}$. PCR products were separated on a $2 \%$ agarose gel (Fig. 2) and the target products were purified using UNIQ-10 Column DNA Gel Extraction kit (Sangon Biotech Co., Ltd., Shanghai, China) according to the manufacturer's protocol. The remaining elution containing the purified DNA products was stored at $-20^{\circ} \mathrm{C}$.

Cloning of the PCR products and gene sequencing. For the ligation of the PCR products and vector, $500 \mathrm{ng}$ of PCR product was added to a total reaction volume of $10 \mu \mathrm{l}$ that contained $0.1 \mu \mathrm{g}$ T-Vector, $2 \mu \mathrm{l}$ T4 DNA Ligase buffer (10X), $0.5 \mu 1 \mathrm{~T} 4$ DNA ligase (all from Takara Bio, Inc.) and distilled $\mathrm{H}_{2} \mathrm{O}$. These reactions were incubated at $22^{\circ} \mathrm{C}$ for $2 \mathrm{~h}$. DNA ligation product $(5 \mu \mathrm{l})$ was added to $100 \mu \mathrm{l}$ of competent DH5 $\alpha$ Escherichia coli cells (Takara Bio, Inc.), mixed and incubated on ice for $30 \mathrm{~min}$. The mixture was subjected to heat shock at $42^{\circ} \mathrm{C}$ for $90 \mathrm{sec}$ and subsequently incubated on ice for $2 \mathrm{~min}$. A total of $900 \mu \mathrm{l}$ super optimal broth with catabolite repression (SOC, Sangon Biotech Co., Ltd.) was added and the mixture was agitated at $37^{\circ} \mathrm{C}$ for $1 \mathrm{~h}$ at $150 \mathrm{rpm}$. Subsequently, $100 \mu \mathrm{l}$ or $900 \mu \mathrm{l}$ of DH5 $\alpha$ cells were spread onto ampicillin-containing Luria broth plates and incubated overnight at $37^{\circ} \mathrm{C}$. Plasmid extraction was performed using a TIANprep Mini Plasmid kit (Tiangen Biotech Co., Ltd., Beijing, China) according to the manufacturer's protocol. A total of $30 \mu \mathrm{l}$ of each elution 
Table I. Clinicopathological characteristics of 35 CRC patients.

\begin{tabular}{lc}
\hline Clinicopathological characteristic & No. of patients $(\%)$ \\
\hline Gender & $22(62.9)$ \\
Male & $13(37.1)$ \\
Female & \\
Age, years & $10(28.6)$ \\
$>65$ & $25(71.4)$ \\
$\leq 65$ & \\
Tumor site & $21(60)$ \\
Colon & $14(40)$ \\
Rectum & \\
Tumor differentiation & $4(11.4)$ \\
G1 & $20(57.2)$ \\
G2 & $11(31.4)$ \\
G3 & \\
Tumor stage & $4(11.4)$ \\
I & $17(48.6)$ \\
II & $11(31.4)$ \\
III & $3(8.6)$ \\
IV & \\
\hline
\end{tabular}

G1, well differentiated; G2, moderate differentiation; G3, poor differentiation.

sample was sent to Invitrogen (Thermo Fisher Scientific, Inc., Waltham, MA, USA) for gene sequencing. The gene mutations identified in the samples are presented in Fig. 3.

Statistical analysis. Statistical analysis was performed using SPSS software (version 22.0; IBM SPSS, Armonk, NY, USA). The McNemar test was used to compare the distribution differences of KRAS and BRAF gene mutations between primary tumor tissues and matched serum exosomes in patients with CRC. The kappa statistic was used to assess the reliability of mutation detection in the tumor tissue and serum exosome samples. The consistency rate was the proportion of the samples with same mutation in the matched serum exosome and tumor tissue of total samples. The gene mutations distribution according to the clinicopathological characteristics of patients were analyzed using the $\chi^{2}$ test. The significance of association between gene mutations and the age of patients were performed using the Student's t-test. $\mathrm{P}<0.05$ was considered to indicate a statistically significant difference.

\section{Results}

KRAS mutation detection in tumor tissues and matched serum exosomes. The mutation status of the KRAS gene was analyzed in 35 tumor tissues and the matched serum exosomes. The spectrum of these mutations is presented in Table III. The KRAS gene was not detected in 2 serum exosome samples. For the other 33 tumor tissue-serum exosome matched samples, 19 (57.6\%) tumor tissues had a mutation in exon 2 or exon 3, of which $12(36.4 \%)$ were at codon 12 of exon $2,5(15.2 \%)$ at
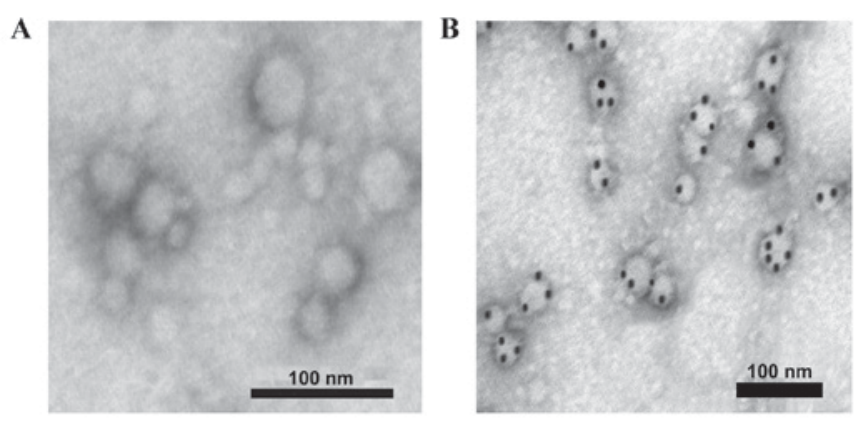

Figure 1. Exosomes obtained from the peripheral blood serum of patients with colorectal cancer. (A) Transmission electron microscopy images of exosomes collected. (B) The presence of serum exosomes expressing cluster of differentiation 63 were confirmed using immunoelectron microscopy (diameter, 30-80 nm).

codon 13 of exon 2 and $2(6.1 \%)$ at codon 61 of exon 3 . The most frequent mutation was G12D (42.1\%) followed by G13D (26.3\%) of all KRAS mutations in tumor tissues. A total of $14(42.4 \%)$ matched serum exosomes contained a mutation in exon 2 or exon 3 , of which there were $8(24.2 \%)$ had a mutation at codon 12 of exon $2,4(12.1 \%)$ at codon 13 of exon 2 and $2(6.1 \%)$ at codon 61 of exon 3 . The most frequent mutation in serum exosomes was also G12D followed by G13D, which represented 35.7 and $28.6 \%$ of all mutations, respectively. There was no significant difference found in the distribution of detected KRAS mutations between tumor tissues and the serum exosomes of patients with $\mathrm{CRC}(\mathrm{P}=0.063)$.

The sensitivity, consistency rate and $\kappa$ score of KRAS gene mutation detection in the serum exosome of patients was calculated (Table III). Comparison of the KRAS mutation status between tumor tissue and the matched serum exosome identified that $84.8 \%$ (28/33) of patients with CRC had the same three KRAS mutations (codon 12, 13 and 61; data not shown). At codon 12 of exon 2, 8 (24.2\%) patients with CRC were positive for a KRAS mutation in their tumor tissue and 5 $(15.1 \%)$ in the serum exosome, giving a total consistency rate of $87.9 \%$. At codon 13 of exon 2, 4 (12.1\%) patients with CRC were identified to have mutant KRAS in their tumor tissue and serum exosome, with $1(3.0 \%)$ patient positive for a KRAS mutation in their tumor tissue only, giving a total consistency rate of $97.0 \%$. The KRAS mutation status was identical in tumor tissue-serum exosome matched samples at codon 61 of exon 3 and therefore the consistency rate was 100\%. Overall, the sensitivity of exosomal mRNA KRAS mutation detection was $73.7 \%$, the specificity was $100 \%$ and the total consistency rate was $94.9 \%(\kappa=0.819)$.

There was no significant association between KRAS mutations and the gender, age, tumor site, tumor differentiation and tumor stage of the patients, analyzed using the $\chi^{2}$ test $(\mathrm{P}>0.05$; Table IV). However, using the Student's t-test, the patients with a KRAS gene mutation at codon 12 of exon 2 were found to be significantly older compared with those patients without this mutation (tumor tissue, $\mathrm{P}=0.002$; serum exosome, $\mathrm{P}=0.022$ ).

\section{BRAF mutation detection in tumor tissues and matched serum} exosomes. BRAF mutations were detected in tumor tissues and matched serum exosomes (Table III). For the 33 tumor tissue-serum exosome matched samples, a BRAF mutation at 
Table II. Primers used for polymerase chain reaction amplification of the KRAS and BRAF genes.

Gene target

Primer sequence (5'-3')

Predicted product size (bp)

\begin{tabular}{ll}
\hline KRAS-exon 2 & F: TACTGGTGGAGTATTTGATAG \\
KRAS-exon 3 & R: TCCTGCACCAGTAATATGCATAT \\
& F: AAGTAAAAGGTGCACTGTAATAA \\
RRAF-exon 15 & F: AACCCACCTATAATGGTGAATATCT \\
KRAS-CDS & R: AACATAATGCTTGCTCTGATAG \\
BRAF-CDS & F: ATGACTGAATATAAACTTGT \\
& R: AGTCCTCATGTACTGGTCCCTC \\
& F: TGGATTACTTACACGCCAAGTCA \\
& R: AATGCATATACATCTGACTGAAAGC
\end{tabular}

KRAS, Kirsten rat sarcoma viral oncogene homolog; BRAF, B-raf serine/threonine kinase proto-oncogene; CDS, cDNA fragment; F, forward; $\mathrm{R}$, reverse.
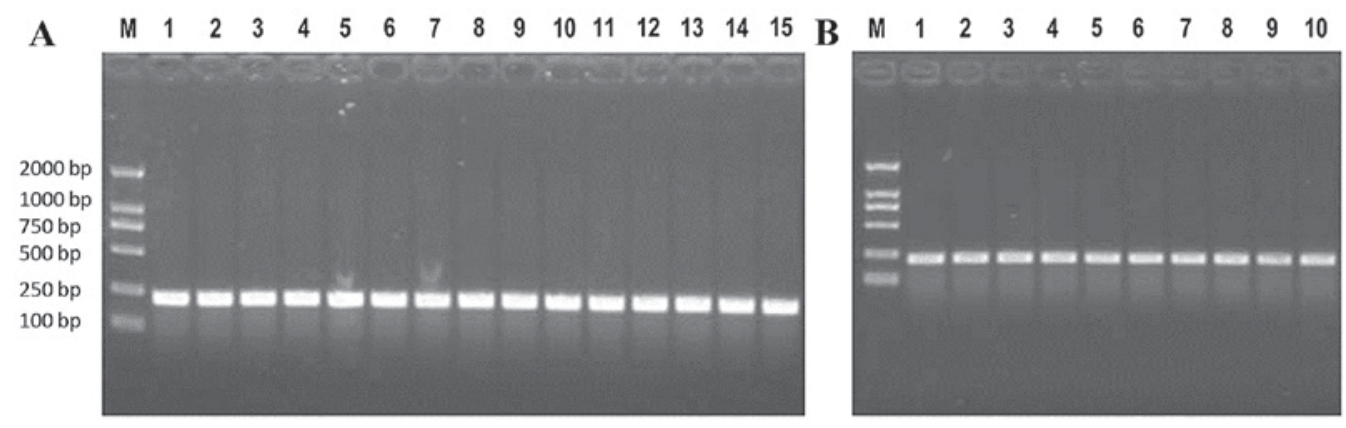

Figure 2. PCR products of KRAS and BRAF gene amplification from patients with CRC. (A) PCR products of KRAS and BRAF gene amplification in tumor tissues were separated using an agarose gel. Lanes 1-5, 243 bp fragment of KRAS-exon 2; lanes 6-10, 235 bp fragment of KRAS-exon 3; lanes 11-15, 243 bp fragment of BRAF-exon 15. (B) PCR products of KRAS and BRAF gene amplification from the matched serum exosomes were separated using an agarose gel. Lanes 1-5: 230 bp fragment of KRAS; lanes 6-10, 238 bp fragment of BRAF. Lane M, DNA marker. PCR, polymerase chain reaction; KRAS, Kirsten rat sarcoma viral oncogene homolog; BRAF, B-raf serine/threonine kinase proto-oncogene; CRC, colorectal cancer.

codon 600 in exon 15 was detected in $8(24.2 \%)$ of the tumor tissues and $6(18.2 \%)$ of the serum exosomes. Gene detection was not possible in 2 serum exosomes, potentially due to a low level of exosomes in the serum. A total of $93.9 \%(31 / 33)$ of patients with CRC had the same BRAF mutation in their tumor tissue and serum exosome matched samples (data not shown), and therefore there was no significant difference in BRAF mutation distribution ( $\mathrm{P}=0.500$; Table III). In 6 (18.2\%) patients with CRC, a mutated BRAF gene was detected in the tumor tissue and serum exosome, and in 2 (6.1\%) patients with CRC the BRAF mutation was detected in their tumor tissue only. The sensitivity of BRAF gene mutation detection in the serum exosome was $75 \%$, the specificity was $100 \%$ and the total consistency rate was $93.9 \%(\kappa=0.820)$. There was no significant association between BRAF mutations and the clinicopathological characteristics of the patients through the $\chi^{2}$ test or the Student's t-test (all P>0.05; Table IV).

\section{Discussion}

Colorectal cancer is becoming the fourth most common malignant carcinoma in recent years (2). Early diagnosis and effective treatment may significantly reduce the mortality rate of this disease and these factors rely on accurate diagnosis, precise tumor staging and gene mutation status analysis. Aside from the traditional chemotherapy recommended by pathological diagnosis, epidermal growth factor receptor (EGFR) -targeted therapy may be administered according to the KRAS and BRAF gene mutation status of patients with CRC (5). Gene evaluation of the tumor tissue is the optimal standard for assessing mutation status, but it is typically performed a single time as it is invasive and costly. However, genomic alterations may differ in primary and metastatic tumor tissues as the disease progresses, and monitoring this requires repetitive genotyping. Other techniques that are in clinical use or are the focus of previous studies are not consistently successful; therefore novel methods allowing repetitive monitoring of these genetic events are being investigated (21-23).

It has been established that cancer initiation and progression are associated with numerous genetic and epigenetic factors, which may be detected through gene alternations in the tumor tissue. DNA, mRNA and miRNA are released into the blood and other bodily fluids from tumor tissues, and may be used to identify tumor-associated genetic and 
Table III. KRAS and BRAF gene mutations in tumor tissues and matched serum exosomes.

\begin{tabular}{|c|c|c|c|c|c|c|}
\hline \multirow[b]{2}{*}{ Gene } & \multirow[b]{2}{*}{$\begin{array}{c}\text { Tumor tissue, } \\
\text { no. }(\%)\end{array}$} & \multirow[b]{2}{*}{$\begin{array}{l}\text { Exosome, } \\
\text { no. }(\%)\end{array}$} & \multirow[b]{2}{*}{$\begin{array}{l}\text { McNemar } \\
\text { test P-value }\end{array}$} & \multicolumn{3}{|c|}{ Detection in exosome } \\
\hline & & & & $\begin{array}{c}\text { Sensitivity } \\
(\%)\end{array}$ & $\begin{array}{l}\text { Total consistency } \\
\text { rate }(\%)\end{array}$ & $\kappa$ score \\
\hline KRAS & & & 0.063 & 73.7 & 94.9 & 0.819 \\
\hline Exon2 (codon 12) & & & 0.125 & 66.7 & 87.9 & 0.718 \\
\hline G12D & $8(24.2)$ & $5(15.1)$ & & & & \\
\hline $\mathrm{G} 12 \mathrm{~V}$ & $3(9.1)$ & $3(9.1)$ & & & & \\
\hline G12A & $1(3.0)$ & $0(0.0)$ & & & & \\
\hline Wild-type & $21(63.7)$ & $25(75.8)$ & & & & \\
\hline Exon2 (codon 13) & & & 1.000 & 80.0 & 97.0 & 0.872 \\
\hline G13D & $5(15.2)$ & $4(12.1)$ & & & & \\
\hline Wild-type & $28(84.8)$ & $29(87.9)$ & & & & \\
\hline Exon3 (codon 61) & & & 1.000 & 100.0 & 100.0 & 1.000 \\
\hline Q61L & $2(6.1)$ & $2(6.1)$ & & & & \\
\hline Wild-type & $31(93.9)$ & $31(93.9)$ & & & & \\
\hline \multicolumn{7}{|l|}{ BRAF } \\
\hline Exon15 (codon 600) & & & 0.500 & 75.0 & 93.9 & 0.820 \\
\hline V600E & $8(24.2)$ & $6(18.2)$ & & & & \\
\hline Wild-type & $25(75.8)$ & $27(81.8)$ & & & & \\
\hline
\end{tabular}

KRAS, Kirsten rat sarcoma viral oncogene homolog; BRAF, B-raf serine/threonine kinase proto-oncogene.

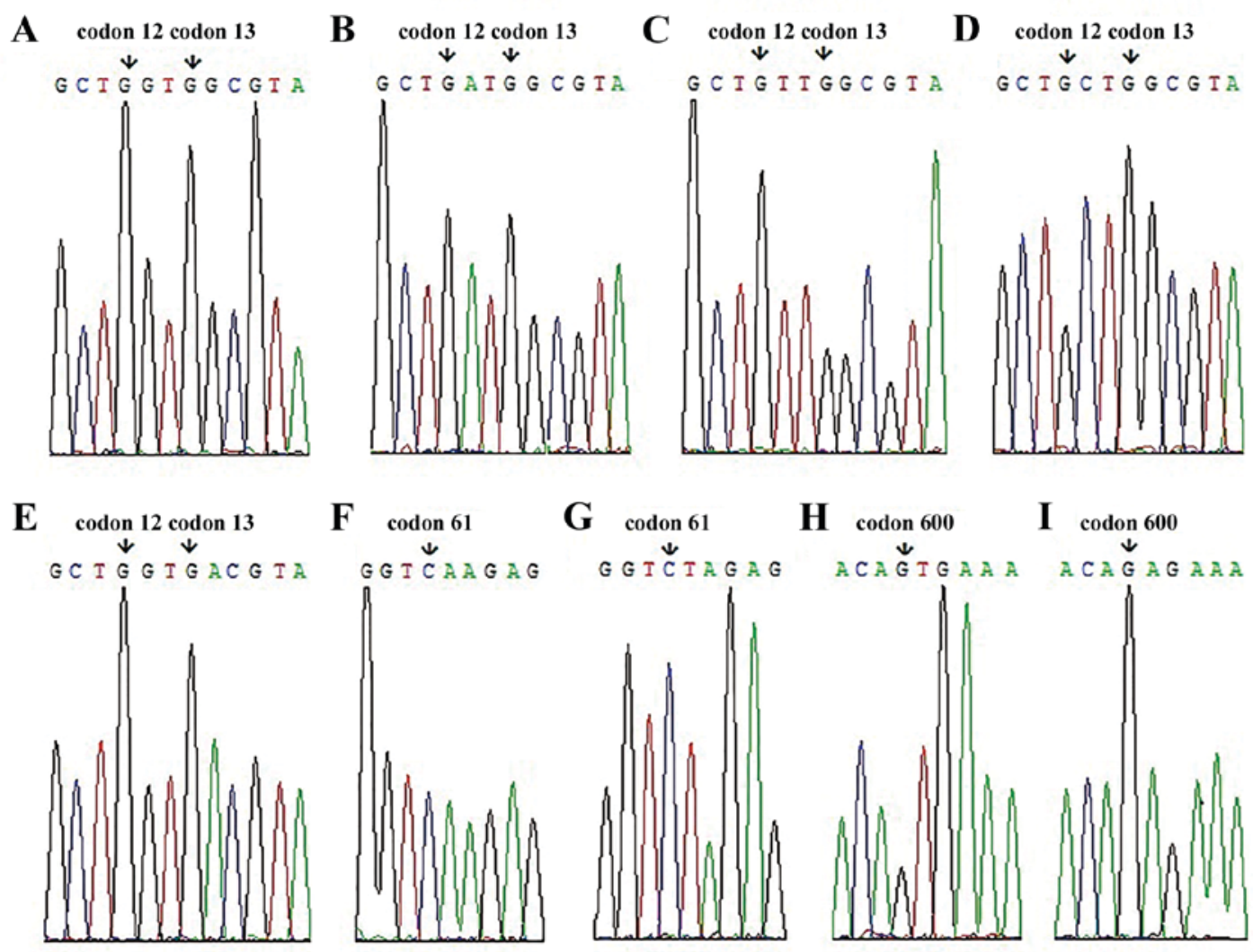

Figure 3. Mutations detected in the KRAS and BRAF genes in patients with colorectal cancer. (A) Wild-type KRAS gene, with arrows indicating codons 12 and 13. (B) G12D mutation of KRAS at codon 12 and wild-type codon 13. (C) G12V mutation of KRAS at codon 12 and wild-type codon 13. (D) G12A mutation of KRAS at codon 12 and wild-type codon 13. (E) Wild-type codon 12 and G13D mutation of KRAS at codon 13. (F) Wild-type codon 61 of KRAS. (G) Q61 L mutation of KRAS at codon 61. (H) Wild-type BRAF, with arrow indicating codon 600. (I) V600E mutation of BRAF at codon 600. KRAS, Kirsten rat sarcoma viral oncogene homolog; BRAF, B-raf serine/threonine kinase proto-oncogene. 
Table IV. Distribution of KRAS and BRAF mutations according to the clinicopathological characteristics of patients with colorectal cancer.

\begin{tabular}{|c|c|c|c|c|c|c|c|c|}
\hline \multirow{3}{*}{$\begin{array}{l}\text { Clinicopathological } \\
\text { characteristic }\end{array}$} & \multicolumn{4}{|c|}{ KRAS mutation } & \multicolumn{4}{|c|}{ BRAF mutation } \\
\hline & \multicolumn{2}{|c|}{ Tumor tissue } & \multicolumn{2}{|c|}{ Exosome } & \multicolumn{2}{|c|}{ Tumor tissue } & \multicolumn{2}{|c|}{ Exosome } \\
\hline & No. $(\%)$ & P-value & No. $(\%)$ & P-value & No. $(\%)$ & P-value ${ }^{a}$ & No. $(\%)$ & P-value \\
\hline \multicolumn{9}{|l|}{ Gender } \\
\hline Male & $11 / 22(50.0)$ & 0.508 & $7 / 20(35.0)$ & 0.284 & $5 / 22(22.7)$ & 1.000 & $3 / 20(15.0)$ & 0.900 \\
\hline Female & $8 / 13(61.5)$ & & $7 / 13(53.8)$ & & $3 / 13(23.1)$ & & $3 / 13(23.1)$ & \\
\hline \multicolumn{9}{|l|}{ Age, years } \\
\hline$>65$ & $8 / 10(80.0)$ & 0.120 & $6 / 10(60.0)$ & 0.335 & $3 / 10(30.0)$ & 0.849 & $3 / 10(30.0)$ & 0.503 \\
\hline$\leq 65$ & $11 / 25(44.0)$ & & $8 / 23(34.8)$ & & $5 / 25(20.0)$ & & $3 / 23(13.0)$ & \\
\hline \multicolumn{9}{|l|}{ Tumor site } \\
\hline Colon & $14 / 21(66.7)$ & 0.072 & $9 / 20(45.0)$ & 0.710 & $5 / 21(23.8)$ & 1.000 & $4 / 20(20.0)$ & 1.000 \\
\hline Rectum & $5 / 14(35.7)$ & & $5 / 13(38.5)$ & & $3 / 14(21.4)$ & & $2 / 13(15.4)$ & \\
\hline \multicolumn{9}{|l|}{ Tumor differentiation } \\
\hline G1 & $0 / 4(0.0)$ & 0.067 & $0 / 3(0.0)$ & 0.203 & $0 / 4(0.0)$ & 0.507 & $0 / 3(0.0)$ & 0.589 \\
\hline $\mathrm{G} 2$ & $12 / 20(60.0)$ & & $10 / 19(52.6)$ & & $5 / 20(25.0)$ & & $3 / 19(15.8)$ & \\
\hline G3 & $7 / 11(63.6)$ & & 4/11 (36.4) & & $3 / 11(27.3)$ & & $3 / 11(27.3)$ & \\
\hline \multicolumn{9}{|l|}{ Tumor stage } \\
\hline I-II & $10 / 21(47.6)$ & 0.332 & 9/19 (47.4) & 0.503 & $3 / 21(14.3)$ & 0.285 & $2 / 19(10.5)$ & 0.383 \\
\hline III-IV & $9 / 14(64.3)$ & & $5 / 14(35.7)$ & & $5 / 14(35.7)$ & & $4 / 14(28.6)$ & \\
\hline
\end{tabular}

G1, well differentiated; G2, moderate differentiation; G3, poor differentiation; KRAS, Kirsten rat sarcoma viral oncogene homolog; BRAF,

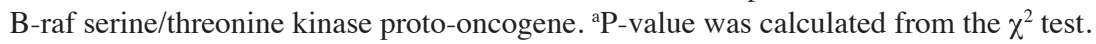

epigenetic alterations. These products may be more informative, specific and accurate compared with protein biomarkers. Sorenson et al (24) and Vasioukhin et al (25) identified that a RAS gene mutation may be detected in blood from cell-free DNA (cfDNA). Koyanagi et al (26) and Mori et al (27) identified that the association between circulating tumor cells and methylated cfDNA can aid in the assessment of disease severity and treatment efficacy in metastatic melanoma. Qiu et al (28) compared the diagnostic value of cfDNA and tumor tissue pathology, the current optimal standard, using a meta-analysis of EGFR mutations in non-small cell lung cancer, with the results suggesting that cfDNA is a highly specific biomarker, but has low sensitivity. However, other sources of cfDNA besides tumors exist and cfDNA is not stable for longer periods of time, therefore cfDNA has low sensitivity as a cancer biomarker (29-31). Previous studies have suggested that quantitatively assaying fecal DNA may provide a non-invasive method with improved sensitivity and specificity for the detection and monitoring of cancer $(32,33)$. Ahlquist (34) identified mutated KRAS and tumor protein 53 (p53) genes in fecal samples from patients with CRC and associated these with the pathogenesis of the disease. However, fecal DNA testing is clinically challenging, as it is costly, time consuming and the results are variable due to DNA degradation $(32,35)$. Despite the challenges, peripheral blood cfDNA and fecal DNA may provide the opportunity to repetitively monitor patients with cancer that are difficult to biopsy, but these methods have not yet been sufficiently successful.
In addition, RNAs are detectable in serum and other bodily fluids, and may also be a stable representation of exosomes (14,36-40). Exosomes are small membrane vesicles that are derived from the endosomal membrane compartment, following the fusion of multi-vesicular bodies with the plasma membrane, and have been found in a number of body fluids, including serum, malignant pleural effusion and urine (41-44). Previous studies have reported that exosomes released from a number of cell types, including immune, mesenchymal and cancer cells, contained identical proteins, mRNAs, miRNAs and DNA fragments (6-9). Ogata-Kawata et al (45) demonstrated that the serum exosome levels of seven miRNAs (let-7a, miR-1229, miR-1246, miR-150, miR-21, miR-223 and miR-23a) were significantly increased in patients with CRC compared with healthy controls, and significantly downregulated following surgical tumor resection. Furthermore, these miRNAs were also identified to be secreted at significantly higher levels in colon cancer cell lines compared with a normal colon-derived cell line (45). Skog et al (9) reported that serum exosomes were positive for the EGFR variant III mutation when the parental glioblastoma cells expressed the same mutation, and that the parental cells exhibited a lower rate of this mutation (28 vs. $47 \%)$. It has been reported that exosomes contain fragments of double-stranded genomic DNA of $>10 \mathrm{~kb}$, which spans all chromosomes, and that mutations in KRAS and p53 have been detected in pancreatic cancer cell lines and the serum from patients with pancreatic cancer (46). Although previous studies have reported that exosomes contain mitochondrial 
DNA, single-stranded DNA and double-stranded genomic DNA $(13,46,47)$, no DNA was detected in exosomes derived from MC/9, BMMC or HMC-1 cells (14). Therefore, the presence of exosomal DNA is not consistent or it may be at low quantities that cannot be analyzed. In addition, compared with membrane-binding proteins, RNA/DNA-binding proteins and lipoprotein complexes, exosomes remain stable despite the presence of RNases, proteases and adverse physical conditions, and may be stored at $4^{\circ} \mathrm{C}$ for $96 \mathrm{~h}$, at $-70^{\circ} \mathrm{C}$ for long periods of time and endure multiple freeze-thaw cycles $(14,48-51)$. Due to these characteristics, exosomal RNA has been considered as a potential novel biomarker for predictive analysis in patients with cancer.

According to previous studies, the KRAS and BRAF gene mutation rate of tumor tissue differs from $20-50 \%$, but is considered to be $35-45 \%$ in patients with CRC (52-54). The fraction of plasma exosomes in patients with $\mathrm{CRC}$ has been reported to be statistically higher compared with healthy controls (55). However, there is a lack of previous studies investigating the association between gene mutations in serum exosome and tumor tissue in patients with CRC. In the present study, KRAS and BRAF gene mutations were detected and the consistency of detected gene mutations was compared between tumor tissues and matched serum exosomes from patients with CRC. The mutation status of tumor tissue served as the reference for detectable mutations and was therefore compared with that of the matched serum exosome. These results demonstrated that the KRAS mutation rate was 57.6 and $42.4 \%$ and BRAF mutation rate was 24.2 and $18.2 \%$, in the tumor tissues and the matched serum exosomes, respectively. In serum exosomes, the sensitivity of KRAS and BRAF mutation detection was 73.7 and $75 \%$ with the total consistency rate of 94.9 and $93.9 \%$, respectively, and the specificity of these two gene mutations were $100 \%$. Previous studies have reported a detection rate of KRAS mutation in cfDNA of 3-50\% in patients with CRC (21-23), thus the efficacy of cfDNA screening remains to be elucidated. The current study hypothesized that the detection rate of mutation in exosomal RNA is higher compared with that in cfDNA, as exosomal RNA were found to be enriched and stable (9). However, the results of the current study demonstrated that the KRAS mutation rate of serum exosomal RNA was similar to that of cfDNA. The similar detection rate may be due to the small sample size, the serum sample preparation, the exosome collection method, the RNA or DNA extraction method, or the sequencing method. In future, purifying the serum exosome RNA may increase the mutation detection rate.

Aging is a consequence of the accumulation of unrepaired naturally-occurring DNA damage. DNA damage typically causes errors in DNA replication or repair, and these errors are the primary source of mutations. Epigenetic alterations may also occur as a result of environmental exposure. The present study demonstrated that CRC patients with a KRAS mutation at codon 12 of exon 2 in their tumor tissue and serum exosome were significantly older compared with those without this mutation. It has also been established that KRAS mutation is significantly higher in CRC patients who are $>50$ years old in the Indian population (56). However, no statistically significant difference in the distribution of age was identified according to KRAS mutation status of patients with CRC in American (57) or Chinese (58) populations. Although the association between KRAS mutation and age has not yet been fully elucidated, it may be suggested that the KRAS gene mutation rate increases with age and other factors, including chemotherapy, radiotherapy and disease progression.

The present study identified that serum exosomal mRNA detection may be effective for the repetitive and non-invasive genotyping of patients with CRC, particularly in patients without the opportunity for a biopsy prior to treatment selection. However, the results of the current study were obtained from a small sample size, thus further studies with a larger sample size in multicenter settings are required to validate these results. The application of exosomes as a cancer biomarker is the focus of current studies, but not yet sufficiently optimized for clinical use. Whether the diagnostic and predictive value of exosomal RNA is similar to DNA from cancer tissues remains to be elucidated, but exosomes have the potential to replace tissue samples in certain situations. Whether exosomes may be used for clinical assessment, including overall survival and progression-free survival, also remains to be elucidated.

In conclusion, exosomal RNA has the potential to replace existing cancer tissue and blood biomarkers to provide information for diagnostic screens, personalized medicine and treatment efficacy.

\section{Acknowledgements}

The present study was supported by the The First Affiliated Hospital of The People's Liberation Army General Hospital (Beijing, China). The authors would like to thank Dr Ning Dong (The First Affiliated Hospital of The People's Liberation Army General Hospital) for aiding with exosome collection and exosomal cDNA synthesis and Dr Jayashri Ghosh (Temple University, Philadelphia, PA, USA) for her assistance in editing the language.

\section{References}

1. Hofsli E, Sjursen W, Prestvik WS, Johansen J, Rye M, Tranø G, Wasmuth HH, Hatlevoll I and Thommesen L: Identification of serum microRNA profiles in colon cancer. Br J Cancer 108: 1712-1719, 2013.

2. National Comprehensive Cancer Network. Guidelines for Treatment of Cancer By Site and Guidelines for Dectection, Prevention, \& Risk Reduction. Available from: https://www. nccn.org/professionals/physician_gls/f_guidelines.asp\#site. Accessed December 24, 2016.

3. Geiger TM and Ricciardi R: Screening options and recommendations for colorectal cancer. Clin Colon Rectal Surg 22: 209-217, 2009.

4. Hol L, de Jonge V, van Leerdam ME, van Ballegooijen M, Looman CW, van Vuuren AJ, Reijerink JC, Habbema JD, Essink-Bot ML and Kuipers EJ: Screening for colorectal cancer: Comparison of perceived test burden of guaiac-based faecal occult blood test, faecal immunochemical test and flexible sigmoidoscopy. Eur J Cancer 46: 2059-2066, 2010.

5. National Comprehensive Cancer Network. Clinical Practice Guidelines in Oncology. Colon cancer Version 2, 2015. http://www.ncen.org /professionals/physician_gls /pdf/colon. pdf. Accessed October 20, 2015.

6. Baj-Krzyworzeka M, Szatanek R, Weglarczyk K, Baran J, Urbanowicz B, Brański P, Ratajczak MZ and Zembala M: Tumour-derived microvesicles carry several surface determinants and mRNA of tumour cells and transfer some of these determinants to monocytes. Cancer Immunol Immunother 55: 808-818, 2006 
7. Deregibus MC, Cantaluppi V, Calogero R, Lo Iacono M, Tetta C, Biancone L, Bruno S, Bussolati B and Camussi G: Endothelial progenitor cell derived microvesicles activate an angiogenic program in endothelial cells by a horizontal transfer of mRNA. Blood 110: 2440-2448, 2007.

8. Ratajczak J, Miekus K, Kucia M, Zhang J, Reca R, Dvorak P and Ratajczak MZ: Embryonic stem cell-derived microvesicles reprogram hematopoietic progenitors: Evidence for horizontal transfer of mRNA and protein delivery. Leukemia 20: 847-856, 2006.

9. Skog J, Würdinger T, van Rijn S, Meijer DH, Gainche L, Sena-Esteves M, Curry WT Jr, Carter BS, Krichevsky AM and Breakefield XO: Glioblastoma microvesicles transport RNA and proteins that promote tumour growth and provide diagnostic biomarkers. Nat Cell Biol 10: 1470-1476, 2008.

10. Kim CW, Lee HM, Lee TH, Kang C, Kleinman HK and Gho YS Extracellular membrane vesicles from tumor cells promote angiogenesis via sphingomyelin. Cancer Res 62: 6312-6317, 2002.

11. Ratajczak J, Wysoczynski M, Hayek F, Janowska-Wieczorek A and Ratajczak MZ: Membrane-derived microvesicles: Important and underappreciated mediators of cell-to-cell communication. Leukemia 20: 1487-1495, 2006.

12. Gould SJ, Booth AM and Hildreth JE: The Trojan exosome hypothesis. Proc Natl Acad Sci USA 100: 10592-10597, 2003.

13. Balaj L, Lessard R, Dai L, Cho YJ, Pomeroy SL, Breakefield XO and Skog J: Tumour microvesicles contain retrotransposon elements and amplified oncogene sequences. Nat Commun 2: 180, 2011.

14. Valadi H, Ekström K, Bossios A, Sjöstrand M, Lee JJ and Lötvall JO: Exosome-mediated transfer of mRNAs and microRNAs is a novel mechanism of genetic exchange between cells. Nat Cell Biol 9: 654-659, 2007.

15. Kim HK, Song KS, Park YS, Kang YH, Lee YJ, Lee KR, Kim HK, Ryu KW, Bae JM and Kim S: Elevated levels of circulating platelet microparticles, VEGF, IL-6 and RANTES in patients with gastric cancer: Possible role of a metastasis predictor. Eur J Cancer 39: 184-191, 2003.

16. Kobayashi M, Salomon C, Tapia J, Illanes SE, Mitchell MD and Rice GE: Ovarian cancer cell invasiveness is associated with discordant exosomal sequestration of Let-7 miRNA and miR-200. J Transl Med 12: 4, 2014.

17. Schwarzenbach H, Hoon DS and Pantel K: Cell-free nucleic acids as biomarkers in cancer patients. Nat Rev Cancer 11: 426-437, 2011.

18. Edge SB and Compton CC: The American Joint Committee on Cancer: The 7th edition of the AJCC cancer staging manual and the future of TNM. Ann Surg Oncol 17: 1471-1474, 2010

19. Xiao W, Dong W, Zhang C, Saren G, Geng P, Zhao H, Li Q, Zhu J, Li G, Zhang S and Ye M: Effects of the epigenetic drug MS-275 on the release and function of exosome-related immune molecules in hepatocellular carcinoma cells. Eur J Med Res 18: 61, 2013.

20. Liu P, Liang H, Xue L, Yang C, Liu Y, Zhou K and Jiang X Potential clinical significance of plasma-based KRAS mutation analysis using the COLD-PCR/TaqMan( $\left({ }^{\circledR}\right)$-MGB probe genotyping method. Exp Ther Med 4: 109-112, 2012.

21. Thierry AR, Mouliere F, El Messaoudi S, Mollevi C, Lopez-Crapez E, Rolet F, Gillet B, Gongora C, Dechelotte P, Robert B, et al: Clinical validation of the detection of KRAS and BRAF mutations from circulating tumor DNA. Nat Med 20: 430-435, 2014

22. Kuo YB, Chen JS, Fan CW, Li YS and Chan EC: Comparison of KRAS mutation analysis of primary tumors and matched circulating cell-free DNA in plasmas of patients with colorectal cancer. Clin Chin Acta 433: 284-289, 2014

23. Perrone F, Lampis A, Bertan C, Verderio P, Ciniselli CM, Pizzamiglio S, Frattini $M$, Nucifora $M$, Molinari $F$, Gallino G, et al: Circulating free DNA in a screening program for early colorectal cancer detection. Tumori 100: 115-121, 2014.

24. Sorenson GD, Pribish DM, Valone FH, Memoli VA, Bzik DJ and Yao SL: Soluble normal and mutated DNA sequences from single-copy genes in human blood. Cancer Epidemiol Biomarkers Prev 3: 67-71, 1994

25. Vasioukhim V, Anker P, Maurice P, Lyautery J, Lederrey C and Stroun M: Point mutations of the N-ras gene in the blood plasma DNA of patients with myelodysplastic syndrome or acute myelogenous leukaemia. Br J Haematol 86: 774-779, 1994.
26. Koyanagi K, Mori T, O'Day SJ, Martinez SR, Wang HJ and Hoon DS: Association of circulating tumor cells with serum tumor-related methylated DNA in peripheral blood of melanoma patients. Cancer Res 66: 6111-6117, 2006.

27. Mori T, O'Day SJ, Umatani N, Martinez SR, Kitago M, Koyanagi K, Kuo C, Takeshima TL, Milford R, Wang HJ, et al: Predictive utility of circulating methylated DNA in serum of melanoma patients receiving biochemotherapy. J Clin Oncol 23 . 9351-9358, 2005

28. Qiu M, Wang J, Xu Y, Ding X, Li M, Jiang F, Xu L and Yin R: Circulating tumor DNA is effective for the detection of EGFR mutation in non-small cell lung cancer: A meta-analysis. Cancer Epidemiol Biomarkers Prev 24: 206-212, 2015.

29. Fleischhacker $M$ and Schmidt B: Circulating nucleic acids (CNAs) and cancer-a survey. Biochim Biophys Acta 1775: 181-232, 2007.

30. Emlen W and Mannik M: Effect of DNA size and strandedness on the in vivo clearance and organ localization of DNA. Clin Exp Immunol 56: 185-192, 1984.

31. Wimberger P, Roth C, Pantel K, Kasimir-Bauer S, Kimmig R and Schwarzenbach $\mathrm{H}$ : Impact of platinum-based chemotherapy on circulating nucleic acid levels, protease activities in blood and disseminated tumor cells in bone marrow of ovarian cancer patients. Int J Cancer 128: 2572-2580, 2011.

32. Ahlquist DA, Sargent DJ, Loprinzi CL, Levin TR, Rex DK, Ahnen DJ, Knigge K, Lance MP, Burgart LJ, Hamilton SR, et al: Stool DNA and occult blood testing for screen detection of colorectal neoplasia. Ann Intern Med 149: 441-450, W481, 2008.

33. Potack J and Itzkowitz SH: Practical advances in stool screening for colorectal cancer. J Natl Compr Canc Netw 8: 81-92, 2010.

34. Ahlquist DA: Next-generation stool DNA testing: Expanding the scope. Gastroenterology 136: 2068-2073, 2009.

35. Davies RJ, Miller R and Coleman N: Colorectal cancer screening: Prospects for molecular stool analysis. Nat Rev Cancer 5: 199-209, 2005

36. Cocucci E, Racchetti G and Meldolesi J: Shedding microvesicles: Artefacts no more. Trends Cell Biol 19: 43-51, 2009.

37. Chen X, Ba Y, Ma L, Cai X, Yin Y, Wang K, Guo J, Zhang Y, Chen J, Guo X, et al: Characterization of microRNAs in serum: A novel class of biomarkers for diagnosis of cancer and other diseases. Cell Res 18: 997-1006, 2008.

38. Cortez MA, Bueso-Ramos C, Ferdin J, Lopez-Berestein G, Sood AK and Calin GA: MicroRNAs in body fluids-the mix of hormones and biomarkers. Nat Rev Clin Oncol 8: 467-477, 2011.

39. Zomer A, Vendrig T, Hopmans ES, van Eijndhoven M, Middeldorp JM and Pegtel DM: Exosomes: Fit to deliver small RNA. Commun Integr Biol 3: 447-450, 2010.

40. Russo F, Di Bella S, Nigita G, Macca V, Laganà A, Giugno R, Pulvirenti A and Ferro A: miRandola: Extracellular circulating microRNAs database. PLoS One 7: e47786, 2012.

41. Caby MP, Lankar D, Vincendeau-Scherrer C, Raposo G and Bonnerot C: Exosomal-like vesicles are present in human blood plasma. Int Immunol 17: 879-887, 2005

42. Andre F, Schartz NE, Movassagh M, Flament C, Pautier P, Morice P, Pomel C, Lhomme C, Escudier B, Le Chevalier T, et al: Malignant effusions and immunogenic tumour-derived exosomes. Lancet 360: 295-305, 2002.

43. Bard MP, Hegmans JP, Hemmes A, Luider TM, Willemsen R, Severijnen LA, van Meerbeeck JP, Burgers SA, Hoogsteden HC and Lambrecht BN: Proteomic analysis of exosomes isolated from human malignant pleural effusions. Am J Respir Cell Mol Biol 31: 114-121, 2004.

44. Pisitkun T, Shen RF and Knepper MA: Identification and proteomic profiling of exosomes in human urine. Proc Natl Acad Sci USA 101: 13368-13373, 2004.

45. Ogata-Kawata H, Izumiya M, Kurioka D, Honma Y, Yamada Y, Furuta K, Gunji T, Ohta H, Okamoto H, Sonoda $\mathrm{H}$, et al: Circulating exosomal microRNAs as biomarkers of colon cancer. PLoS One 9: e92921, 2014.

46. Kahlert C, Melo SA, Protopopov A, Tang J, Seth S, Koch M, Zhang J, Weitz J, Chin L, Futreal A and Kalluri R: Identification of double-stranded genomic DNA spanning all chromosomes with mutated KRAS and p53 DNA in the serum exosomes of patients with pancreatic cancer. J Biol Chem 289: 3869-3875, 2014.

47. Guescini M, Guidolin D, Vallorani L, Casadei L, Gioacchini AM and Tibollo P, Battistelli M, Falcieri E, Battistin L, Agnati LF and Stocchi V: C2C12 myoblasts release micro-vesicles containing mtDNA and proteins involved in signal transduction. Exp Cell Res 316: 1977-1984, 2010 
48. Taylor DD and Gercel-Taylor C: MicroRNA signatures of tumor-derived exosomes as diagnostic biomarkers of ovarian cancer. Gynecol Onco 110: 13-21, 2008.

49. Mitchell PS, Parkin RK, Kroh EM, Fritz BR, Wyman SK, Pogosova-Agadjanyan EL, Peterson A, Noteboom J, O'Briant KC Allen A, et al: Circulating microRNAs as stable blood-based markers for cancer detection. Proc Natl Acad Sci USA 105: 10513-10518, 2008.

50. Vickers KC, Palmisano BT, Shoucri BM, Shamburek RD and Remaley AT: MicroRNAs are transported in plasma and delivered to recipient cells by high-density lipoproteins. Nat Cell Biol 13: 423-433, 2011.

51. Khalyfa A and Gozal D: Exosomal miRNAs as potential biomarkers of cardiovascular risk in children. J Transl Med 12: $162,2014$.

52. Benvenuti S, Sartore-Bianchi A, Di Nicolantonio F, Zanon C, Moroni M, Veronese S, Siena S and Bardelli A: Oncogenic activation of the RAS/RAF signaling pathway impairs the response of metastatic colorectal cancers to antie-epidermal growth factor receptor antibody therapies. Cancer Res 67: 2643-2648, 2007.

53. Neumann J, Zeindl-Eberhart E, Kirchner T and Jung A: Frequency and type of KRAS mutations in routine diagnostic analysis of metastatic colorectal cancer. Pathol Res Pract 205 : 858-862, 2009.
54. Shen H, Yuan Y, Hu H, Zhong X, Ye XX, Li MD, Fang WJ and Zheng S: Clinical significance of K-ras and BRAF mutations in Chinese colorectal cancer patients. World J Gastroenterol 17: 809-816, 2011.

55. Silva J, Garcia V, Rodriguez M, Compte M, Cisneros E, Veguillas P, Garcia JM, Dominguez G, Campos-Martin Y, Cuevas J, et al: Analysis of exosome release and its prognostic value in human colorectal cancer. Gens Chromosomes Cancer 51: 409-418, 2012.

56. Bisht S, Ahmad F, Sawaimoon S, Bhatia S and Das BR: Molecular spectrum of KRAS, BRAF and PIK3CA gene mutation: Determination of frequency, distribution pattern in Indian colorectal carcinoma. Med Oncol 31: 124, 2014.

57. Phipps AI, Buchanan DD, Makar KW, Win AK, Baron JA, Lindor NM, Potter JD and Newcomb PA: KRAS-mutation status in relation to colorectal cancer survival: The joint impact of correlated tumour markers. Br J Cancer 108: 1757-1764, 2013.

58. Mao C, Zhou J, Yang Z, Huang Y, Wu X, Shen H, Tang J and Chen Q: KRAS, BRAF and PIK3CA mutations and the loss of PTEN expression in Chinese patients with colorectal cancer. PLoS One 7: e36653, 2012. 